\title{
Contrasting transfer of polonium-210 and lead-210 across three trophic levels in marine plankton
}

\author{
Gillian M. Stewart ${ }^{1, *}$, Scott W. Fowler ${ }^{2}$, Jean-Louis Teyssié ${ }^{2}$, Olivier Cotret ${ }^{2}$, \\ J. Kirk Cochran ${ }^{1}$, Nicholas S. Fisher ${ }^{1}$ \\ ${ }^{1}$ Marine Sciences Research Center, Stony Brook University, Stony Brook, New York 11794-5000, USA \\ ${ }^{2}$ Marine Environment Laboratory, International Atomic Energy Agency, 4 Quai Antoine 1er, 98000 Monaco
}

\begin{abstract}
The naturally occurring radionuclides ${ }^{210} \mathrm{Po}$ and ${ }^{210} \mathrm{~Pb}$ can be used as geochemical tracers in marine systems, but their interactions with biota in surface waters need to be understood before oceanographic data can be interpreted unambiguously. We compared the food chain dynamics of these radionuclides in plankton assemblages by measuring the uptake and trophic transfer of ${ }^{210} \mathrm{Po}$ and ${ }^{210} \mathrm{~Pb}$ from phytoplankton to brine shrimp Artemia sp. to euphausiids Meganyctiphanes norvegica under controlled laboratory conditions. The ratio of ${ }^{210} \mathrm{Po}:{ }^{210} \mathrm{~Pb}$ within organisms increased 5- to 12-fold with each trophic level (phytoplankton to grazer to carnivore), reflecting a preferential bioaccumulation of ${ }^{210} \mathrm{Po}$ over ${ }^{210} \mathrm{~Pb}$. M. norvegica assimilated $44 \%$ of the polonium ingested but only $3.5 \%$ of the ${ }^{210} \mathrm{~Pb}$ ingested. Because ${ }^{210} \mathrm{~Pb}$ was unassimilated, the ratio of ${ }^{210} \mathrm{Po}:{ }^{210} \mathrm{~Pb}$ was 1 to 2 orders of magnitude smaller in zooplankton fecal pellets than in the animals producing them. These results suggest that in surface waters ${ }^{210}$ Po has the potential to build up in food chains and be biologically recycled, whereas ${ }^{210} \mathrm{~Pb}$ would not build up in marine food chains and would display shorter residence times. Since euphausiids comprise an important link between small plankton and larger predatory animals in many marine ecosystems, they may serve as an important conduit of ${ }^{210} \mathrm{Po}$ to those predators consumed as seafood by humans.
\end{abstract}

KEY WORDS: Polonium $\cdot$ Lead $\cdot$ Trophic transfer $\cdot$ Plankton $\cdot$ Bioaccumulation $\cdot$ Residence time Artemia $\cdot$ Krill

\section{INTRODUCTION}

For many elements that bioaccumulate in marine organisms, the greatest bioconcentration from water into tissues occurs at the bottom of the food chain (IAEA 2004). Once associated with phytoplankton, a metal or metalloid can be transferred to higher trophic levels, or the passage up the food chain can be blocked if key components of the food chain (e.g. herbivores) do not assimilate the ingested metal and instead package it into sinking fecal matter (Fisher \& Reinfelder 1995). One element that has received increasing attention as both a prospective geochemical tracer and as a potential source of high levels of radioactivity to marine organisms and humans is polonium-210. ${ }^{210} \mathrm{Po}$ $\left(t_{1 / 2}=138 \mathrm{~d}\right)$ is a naturally occurring radionuclide formed by the beta decay of its grandparent ${ }^{210} \mathrm{~Pb}$ $\left(t_{1 / 2}=22\right.$ yr) via ${ }^{210} \mathrm{Bi}$. Unlike ${ }^{210} \mathrm{Po},{ }^{210} \mathrm{~Pb}$ is not effectively accumulated in marine organisms (Carvalho \& Fowler 1993), but is still used as a geochemical tracer. The geochemical cycling of both ${ }^{210} \mathrm{Po}$ and ${ }^{210} \mathrm{~Pb}$ has been used to study particle scavenging, water mass mixing and vertical fluxes (Cherry et al. 1975, Cochran et al. 1983, Fowler \& Knauer 1986, Nozaki et al. 1997, Masqué et al. 2002), although detailed studies that provide mechanistic explanations for their different behaviors are still largely lacking. Further, efforts to find a specific radiotracer of carbon flux in the oceanic water column have explored the application of ${ }^{210} \mathrm{Po}$ to complement work with ${ }^{234} \mathrm{Th}$ (Friedrich \& Rutgers van der Loeff 2002).

The concentration of ${ }^{210} \mathrm{Po}$ in seafood has received much interest from the marine scientific community because it is a high-energy alpha-emitter that accounts for 
most of the radiation dose received by marine organisms (Shannon \& Cherry 1967, Shannon et al. 1970, Heyraud \& Cherry 1979), even those exposed to anthropogenic radioactive releases into coastal waters (Aarkrog et al. 1997). Consumption of seafood could increase the radiation dose to humans by an order of magnitude beyond background radiation (Thomas et al. 2003). Bustamante et al. (2002), for example, found that activity from the ${ }^{210} \mathrm{Po}$ alpha particles consumed in $4 \mathrm{~kg}$ of scallops would effectively account for the current human annual exposure limit of $1 \mathrm{mSv}$.

The uptake of ${ }^{210} \mathrm{Po}$ has been examined from the dissolved phase to marine phytoplankton (Fisher et al. 1983a, Stewart \& Fisher 2003a) and from phytoplankton to zooplankton grazers (Stewart \& Fisher 2003b). We are not aware of controlled experiments that examined the trophic transfer of this element from herbivores to carnivorous plankton, although it can be inferred from field studies (Heyraud et al. 1976) that it is likely that such transfer occurs in plankton assemblages. It has been assumed that assimilation of metals in herbivore grazers controls the ultimate fate of metals in food chains and is sufficient to predict bioaccumulation in higher animals (Fisher \& Reinfelder 1995), but this has not been carefully examined under controlled conditions. To explore this issue further, we conducted experiments to measure the transfer of ${ }^{210} \mathrm{Po}$ from herbivorous zooplankton (brine shrimp) to the euphausiid Meganyctiphanes norvegica, or 'northern krill,' feeding as a carnivore. We also compared the uptake of ${ }^{210} \mathrm{Po}$ with that of ${ }^{210} \mathrm{~Pb}$ in these plankton assemblages. Many studies have confirmed that marine animals can take up metals and radionuclides from the dissolved phase and from food (Reinfelder et al. 1998, Wang \& Fisher 1999). Because the uptake of ${ }^{210} \mathrm{Po}$ from water has been shown to be a non-significant $(<3 \%)$ route of exposure in crustaceans (Carvalho \& Fowler 1993, 1994, Stewart \& Fisher 2003b), we focused solely on uptake through food in these experiments.

Euphausiids (Crustacea: Euphausiacea) are the second most common net zooplankton $(>20 \mu \mathrm{m})$ globally after copepods, and form a 'bridge' between the plankton and larger predators such as fishes, cephalopods and mammals. They can be grazers, filter-feeders, predators, or detritivores (Rupert \& Barnes 1994), but enzyme activity and fatty acid biomarkers indicate that Meganyctiphanes norvegica is primarily omnivorous (Mayzaud et al. 1999, Buchholz \& Saborowski 2000, Virtue et al. 2000). Euphausiids are important prey for many commercially valuable fishes and invertebrates including blue whiting, hake, mackerel (Bozzano et al. 1997, Cabral \& Murta 2002) and the Norway lobster Nephrops norvegicus (Cristo \& Cartes 1998). Further, krill are not only an important part of the marine food chain, they also comprise a large fishery in themselves for both human consumption and animal feed (Kils \& Klages 1979).

The concentrations of trace metals (Fowler 1977, Stoeppler \& Brandt 1979, Locarini \& Presley 1995, Nygard et al. 2001), anthropogenic radionuclides (Antezana \& Fowler 1972, Higgo et al. 1977, Marzano et al. 2000, Heldal et al. 2003) and ${ }^{210}$ Po (Cherry et al. 1975, Heyraud \& Cherry 1979) have been measured in euphausiids from the Antarctic, Pacific, Mediterranean and Atlantic. In all these studies, Meganyctiphanes norvegica, the Antarctic krill Euphausia superba, and other euphausiid species provided a clear link between the plankton and larger organisms and were shown to play an important role in the transfer of these elements in marine ecosystems.

It is necessary to assess the assimilation and retention of metals, including ${ }^{210} \mathrm{Po}$ and ${ }^{210} \mathrm{~Pb}$, in marine zooplankton in order to evaluate the build-up of these metals in marine food chains. This information is required for understanding both the biogeochemical cycling of these elements and their potential for exerting toxic effects, including those to humans. ${ }^{210} \mathrm{~Pb}$ is used as a tracer of particle flux in marine systems and

${ }^{210}$ Po has the potential to be used as a specific tracer of particulate organic carbon, and yet very few comparative assimilation and trophic transfer studies have been performed with these elements. We therefore conducted a study to assess these processes in simple marine food chains to provide a mechanistic basis for understanding oceanographic observations on the distributions of these radionuclides.

\section{MATERIALS AND METHODS}

The diatom Thalassiosira pseudonana and the prymnesiophyte Isochrysis galbana were grown in seawater enriched with $f / 2$ nutrients (Guillard \& Ryther 1962) until the stationary phase, after which they were radiolabeled for $48 \mathrm{~h}$ with ${ }^{210} \mathrm{Po}$ and ${ }^{210} \mathrm{~Pb}$; this is sufficient time to uniformly label these cells (Stewart \& Fisher 2003a). Microliter additions of these radioisotopes were added to the seawater; the isotopes were in radioactive equilibrium and came from a stock solution in $1 \mathrm{~N}$ $\mathrm{HNO}_{3}$. Microliter volumes of $\mathrm{NaOH}$ immediately following the radioisotope addition ensured that the $\mathrm{pH}$ of the seawater was not affected by the radiolabeling. The activity of the radionuclide solution was $19.8 \mathrm{kBq}^{-1}$.

Aliquots of each of the phytoplankton cell suspensions for a total of $5 \times 10^{4}$ cells ml $\mathrm{m}^{-1}$ (or about $1 \mathrm{mg}$ dry wt $\mathrm{l}^{-1}$ ) were then presented to 1000 adult brine shrimp Artemia sp. for $56 \mathrm{~h}$. Thus the Artemia sp. were presented with a mixed algal diet of contrasting cell types, one a naked flagellate, the other with a siliceous test. The exposure time was sufficient to attain enough 
radioactivity in the brine shrimp to follow the subsequent transfer to euphausiids. Because the algal cells were not removed from their radioactive media, Artemia sp. were exposed to the radioisotopes in both particulate (13\% of total radioactivity) and dissolved (87\% of total radioactivity) forms.

Euphausiids Meganyctiphanes norvegica were collected using a $200 \mu \mathrm{m}$ plankton net at $20 \mathrm{~m}$ depth at the French JGOFS time series DYFAMED site $\left(43^{\circ} 25^{\prime} \mathrm{N}\right.$, $\left.7^{\circ} 52^{\prime} \mathrm{E}\right)$ in the NW Mediterranean. They were kept in 21 of unfiltered seawater at $15^{\circ} \mathrm{C}$ in the dark for $36 \mathrm{~h}$ until arrival at the laboratory, at which time each individual was transferred into $400 \mathrm{ml}$ of $0.2 \mu \mathrm{m}$ filtered seawater, that was changed daily. The 13 experimental euphausiids were starved for $1 \mathrm{~d}$ prior to the beginning of the experiment.

Before feeding Artemia sp. to Meganyctiphanes norvegica, 50 radiolabeled Artemia sp. were gammacounted and alpha-counted for ${ }^{210} \mathrm{~Pb}$ and ${ }^{210} \mathrm{Po}$ activity, respectively. ${ }^{210} \mathrm{~Pb}$ measurements were performed at $46 \mathrm{keV}$ using a Pharmacia-Wallac LKB gamma spectrometer equipped with a well-type NaI detector. ${ }^{210} \mathrm{Po}$ was plated onto silver discs (Flynn 1968) in the presence of ${ }^{209} \mathrm{Po}$ as a yield monitor, and ${ }^{210} \mathrm{Po}$ activities were determined by alpha spectrometry. The fecal pellets were also collected from the radiolabeled Artemia sp. and analyzed for ${ }^{210} \mathrm{~Pb}$ and ${ }^{210} \mathrm{~Pb}$ activities. Then, batches of 15 Artemia sp. were gamma-counted and presented to each euphausiid in separate flasks. At the same time, 15 Artemia sp. were placed in filtered seawater under the same conditions, as a control to evaluate the loss of ${ }^{210} \mathrm{Po}$ and ${ }^{210} \mathrm{~Pb}$ from the brine shrimp to the dissolved phase during the euphausiid feeding period. The euphausiids fed for 5 to $7 \mathrm{~h}$ in the dark at $15^{\circ} \mathrm{C}$.

After feeding, the number of Artemia sp. remaining in each flask was counted to determine how many had been eaten. The euphausiid was removed, gammacounted for ${ }^{210} \mathrm{~Pb}$, and placed in another flask with filtered seawater and 5 non-radioactive Artemia sp. overnight to purge their guts of radiolabeled food (Fisher et al. 1983b). When the individual euphausiids had finished feeding on the Artemia sp., the activities of ${ }^{210} \mathrm{Po}$ and ${ }^{210} \mathrm{~Pb}$ were determined for the seawater, the fecal material, and the remaining Artemia sp. in each feeding flask (including the Artemia sp. control). After gut evacuation, the euphausiids were collected for gamma- and alpha-counting and their total fecal material was also collected. The activity of ${ }^{210} \mathrm{Po}$ and ${ }^{210} \mathrm{~Pb}$ in the fecal pellets of the control Artemia sp. was normalized to how many Artemia sp. survived the feeding and deducted from the total radioactivity in each euphausiid's fecal pellets. The very small ( $<5 \%$ in all cases) amount of ${ }^{210} \mathrm{Po}$ and ${ }^{210} \mathrm{~Pb}$ radioactivity on the euphausiids that did not eat Artemia sp. was subtracted from the euphausiid counts to exclude uptake from the dissolved phase.

\section{RESULTS}

The activity of ${ }^{210} \mathrm{Po}$ and ${ }^{210} \mathrm{~Pb}$ in the cellular suspension was measured at the end of labeling and the activity was within $5 \%$ of the original activity, indicating that there was no significant loss of radionuclides to volatilization or sorption to flask walls. The uptake and cellular distribution of polonium and lead in the phytoplankton was assumed to follow the established trends previously described by Fisher et al. (1983a) and Stewart \& Fisher (2003a). Before being fed to Artemia sp., the phytoplankton cells had a ${ }^{210} \mathrm{Po}:{ }^{210} \mathrm{~Pb}$ activity ratio of $1: 1$.

After $56 \mathrm{~h}$ the ${ }^{210} \mathrm{~Pb}$ activity in the Artemia sp. appeared stabilized at $22 \pm 2.6 \mathrm{~Bq}$ individual $^{-1}$ (Fig. 1). ${ }^{210} \mathrm{Po}$ activity was not assessed due to the destructive nature of alpha-sampling, but partitioning between dissolved and particulate phases (Artemia sp. in this case) was assumed to be in equilibrium based on uptake kinetics (described in detail in Stewart \& Fisher $2003 \mathrm{a}, \mathrm{b})$. After feeding, some ${ }^{210} \mathrm{~Pb}$ desorbed from the radiolabeled Artemia sp., resulting in a ${ }^{210} \mathrm{~Pb}$ activity of $12.8 \pm 3.2 \mathrm{~Bq}$ individual ${ }^{-1}$. The activity of ${ }^{210} \mathrm{Po}$ on Artemia sp. at the end of labeling was $66.5 \pm 4.4 \mathrm{~Bq}$ individual ${ }^{-1}$. Thus, the ${ }^{210} \mathrm{Po}:{ }^{210} \mathrm{~Pb}$ activity ratio in the brine shrimp at the end of the experiment was about 5.2 , a value within the range of such ratios measured in natural zooplankton samples.

Of the 13 experimental euphausiids, 4 did not eat Artemia sp. during the feeding period. These krill allowed us to calculate the uptake by the euphausiids of radioactivity that desorbed from the brine shrimp into the dissolved phase during feeding. The very small amount of activity $(<2 \%$ of total activity in each flask) measured in the non-eating euphausiids was subtracted from the total activity of the feeding

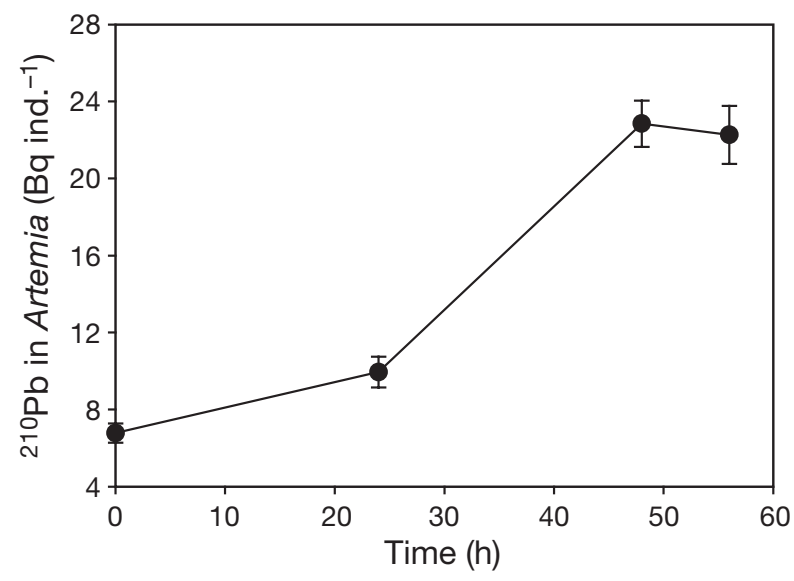

Fig. 1. Artemia sp. Uptake of ${ }^{210} \mathrm{~Pb}\left(\mathrm{~Bq}\right.$ individual $\left.{ }^{-1}\right)$ over time in Artemia sp. feeding on Thalassiosira pseudonana and Isochrysis galbana 
euphausiids to determine the radionuclides taken up by ingestion only. There was no statistical correlation between the size of the euphausiid individuals and the number of Artemia sp. eaten. When normalized to weight, the average final ${ }^{210} \mathrm{Po}$ activity was $30.8 \pm$ $0.9 \mathrm{~Bq} \mathrm{mg}^{-1}$ in the large individuals (300 $\mathrm{mg}$ wet wt) and $32.9 \pm 0.5 \mathrm{~Bq} \mathrm{mg}^{-1}$ in the small euphausiids (100 mg wet wt). The ${ }^{210} \mathrm{Po}$ content of Meganyctiphanes norvegica increased linearly with the number of Artemia sp. that were consumed, in contrast to the minimal accumulation of ${ }^{210} \mathrm{~Pb}$ in the euphausiids, regardless of the number of Artemia sp. eaten (Fig. 2).

The total activities of ${ }^{210} \mathrm{Po}$ and ${ }^{210} \mathrm{~Pb}$ ingested by each euphausiid were calculated by multiplying the number of brine shrimp eaten by the activities of ${ }^{210} \mathrm{Po}$ and ${ }^{210} \mathrm{~Pb}$ in each Artemia sp. individual. These activities should be taken as upper limits of the exposure to Meganyctiphanes norvegica, as it is assumed that there was no loss of polonium or lead from the transfer of Artemia sp. to the euphausiids via 'sloppy feeding.' After gut clearance in the euphausiids, the total activity of each $M$. norvegica and its fecal material was calculated and compared to the total ${ }^{210} \mathrm{Po}$ and ${ }^{210} \mathrm{~Pb}$ ingested. The percentages of total ingested ${ }^{210} \mathrm{Po}$ and ${ }^{210} \mathrm{~Pb}$ remaining in the euphausiids and found in the feces are shown in Fig. 3, and accounted for $>70 \%$ of the total activity ingested. The remainder (typically 20 to $30 \%$ ) was assumed to be in the dissolved phase following either desorption from food or soluble excretion from the euphausiids, but was below detection limits due to dilution or incomplete collection of fecal material.

There was a striking difference between the partitioning of the ${ }^{210} \mathrm{~Pb}$ and ${ }^{210} \mathrm{Po}$ in the euphausiids. Only

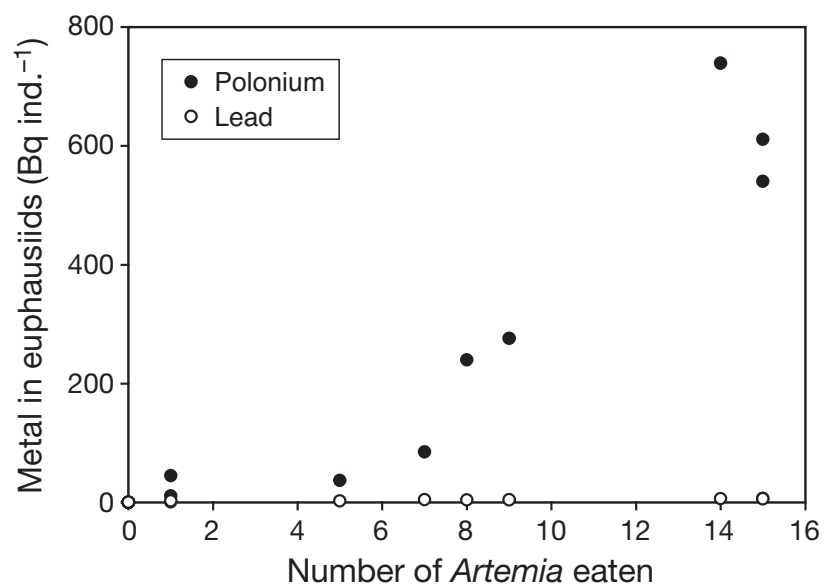

Fig. 2. Meganyctiphanes norvegica. Assimilated ${ }^{210} \mathrm{Po}$ and ${ }^{210} \mathrm{~Pb}$ in euphausiids in relation to number of Artemia sp. consumed during feeding. Relationship between ${ }^{210}$ Po concentration in euphausiids and number of Artemia sp. eaten can be modeled by linear equation with a slope of 40 and a $y$-intercept of $-39.7\left(r^{2}=0.88\right)$

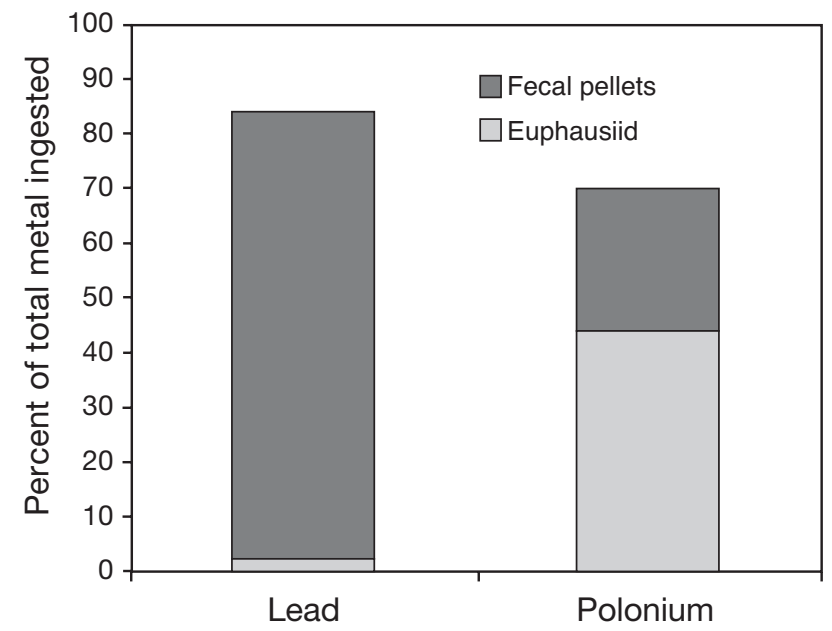

Fig. 3. Meganyctiphanes norvegica. ${ }^{210} \mathrm{Po}$ and ${ }^{210} \mathrm{~Pb}$ in euphausiids and their fecal pellets as a percent of total radionuclides ingested with labeled Artemia sp.

$3.5 \pm 2.5 \%$ of the ${ }^{210} \mathrm{~Pb}$ ingested remained in the euphausiids, compared to $84 \pm 15 \%$ in the fecal pellets. In contrast, approximately $44 \pm 19 \%$ of the ingested ${ }^{210}$ Po remained in the euphausiids after gut clearance, with only $26 \pm 11 \%$ in the fecal pellets. Thus, the assimilation efficiency (AE) of ${ }^{210} \mathrm{Po}$ (calculated as the percent of ingested activity that remained in the euphausiid after gut evacuation) was 12.6 times that of ${ }^{210} \mathrm{~Pb}$ in the euphausiids. Given the ${ }^{210} \mathrm{Po}:{ }^{210} \mathrm{~Pb}$ activity ratio in the Artemia sp. after feeding (see next paragraph), we can surmise that the ${ }^{210} \mathrm{Po} \mathrm{AE}$ was approximately 5 times higher than the ${ }^{210} \mathrm{~Pb} \mathrm{AE}$ in Artemia sp.

The activity ratio of ${ }^{210} \mathrm{Po}:{ }^{210} \mathrm{~Pb}$ was calculated in each stage of the experiment, and is shown in Fig. 4. The ratio in the phytoplankton cells was not much higher than the equilibrium solution (1:1) in which they were labeled. The preferential assimilation of ${ }^{210} \mathrm{Po}$

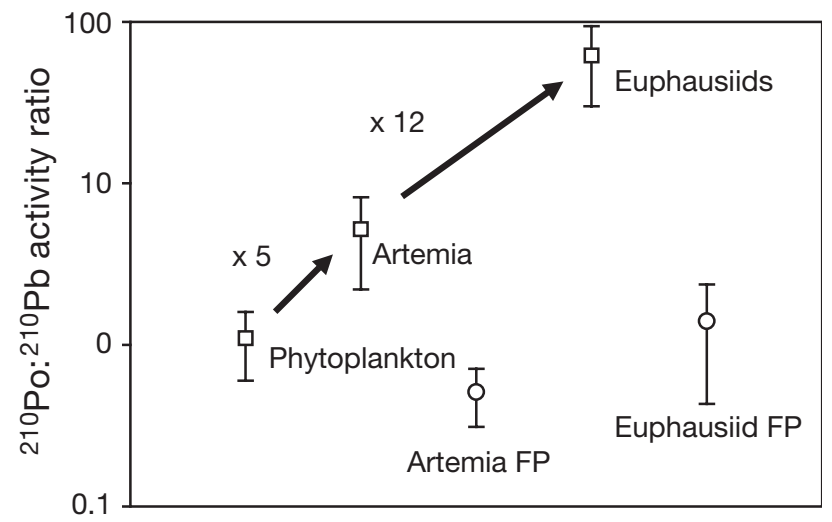

Fig. 4. Mean $( \pm 1 \mathrm{SD}){ }^{210} \mathrm{Po}:{ }^{210} \mathrm{~Pb}$ ratio in phytoplankton, brine shrimp Artemia sp., and euphausiids Meganyctiphanes norvegica and in Artemia sp. and euphausiid fecal pellets (FP). $Y$-axis is in log-scale 
over ${ }^{210} \mathrm{~Pb}$ resulted in an activity ratio close to 5 for Artemia sp., and a ratio of 62 for Meganyctiphanes norvegica. The ${ }^{210} \mathrm{Po}:{ }^{210} \mathrm{~Pb}$ activity ratio in the euphausiid fecal pellets was close to 1 , whereas the ratio in the brine shrimp fecal pellets was 0.51. Thus, Artemia sp. were about 10 times more enriched in ${ }^{210} \mathrm{Po}$ than in ${ }^{210} \mathrm{~Pb}$ relative to their fecal pellets, and M. norvegica were about 60 times more enriched in ${ }^{210} \mathrm{Po}$ than in ${ }^{210} \mathrm{~Pb}$.

\section{DISCUSSION}

Although a few experiments have demonstrated that ${ }^{210} \mathrm{Po}$ can be transferred efficiently from marine phytoplankton to herbivores (Wildgust et al. 2000, Stewart \& Fisher 2003b), we believe that this study is the first to evaluate the trophic transfer of this important radionuclide to carnivorous plankton. We expected that the assimilation efficiency (AE) of ${ }^{210} \mathrm{Po}$ through predation would be as high as, or higher than, the AE via herbivory. Twining \& Fisher (2004) found that AEs of some trace metals were higher in copepods feeding on protozoans than in copepods feeding on phytoplankton due to the cellular distribution of the elements in the various cells used in the feeding studies. Wallace \& Lopez (1996) determined that changing the metal exposure pathway in prey could affect assimilation in predators, with only metals in certain fractions of prey organisms being available to higher trophic levels. Whereas the assimilation of ${ }^{210}$ Po by herbivores (Stewart \& Fisher 2003b), like other metals (Reinfelder \& Fisher 1991), is strongly correlated with its cytoplasmic distribution in phytoplankton food cells, it can be inferred from our euphausiid results that a greater fraction of total ${ }^{210} \mathrm{Po}$ than of total ${ }^{210} \mathrm{~Pb}$ was in a labile pool in the Artemia sp. prey.

Assimilation efficiencies of ingested radionuclides in our experiments were comparable to values found in crustaceans by other authors. The AE in prawns fed ${ }^{210}$ Po-labeled food was $35 \%$ (Carvalho \& Fowler 1994), and the AE was estimated to be at least 5 times higher for $\mathrm{Po}$ than $\mathrm{Pb}$ in shrimp (Carvalho \& Fowler 1993). Furthermore, the turnover of ${ }^{210} \mathrm{Po}$ was much slower than that of ${ }^{210} \mathrm{~Pb}$ in shrimp tissue during extended depuration experiments (Carvalho \& Fowler 1993). The same results were found in herbivorous copepods, where the AE ranged from 20 to $55 \%$ depending on the algal diet (Stewart \& Fisher 2003b). The high AEs and low excretion rates of ${ }^{210} \mathrm{Po}$ and the low AEs of ${ }^{210} \mathrm{~Pb}$ generally seen in marine zooplankton (Fisher et al. 1995, and this study) explain the high ${ }^{210} \mathrm{Po}:{ }^{210} \mathrm{~Pb}$ activity ratios (10 to 1000) in invertebrate tissues (Carvalho \& Fowler 1994).
The assimilation of ${ }^{210} \mathrm{Po}$ and ${ }^{210} \mathrm{~Pb}$ observed in our work should be considered in the context of previous field and biochemical investigations of these radioisotopes in other marine crustaceans. The uptake of ${ }^{210} \mathrm{Po}$ and ${ }^{210} \mathrm{~Pb}$ into larger crustaceans such as shrimp (Cherry \& Heyraud 1982, Heyraud et al. 1988, Carvalho \& Fowler 1993, 1994), isopods (Stepnowski \& Skwarzec 2000) and lobsters (Heyraud et al. 1987, Durand et al. 2002) can be explained by the higher assimilation of ${ }^{210} \mathrm{Po}$ than ${ }^{210} \mathrm{~Pb}$ that we found. Some of the highest ${ }^{210} \mathrm{Po}$ concentrations recorded in natural samples are found in the hepatopancreas of these crustaceans (Cherry \& Heyraud 1982), possibly due to sulfur-rich, metal-binding proteins found in high concentrations in these organs. Durand et al. (2002) showed that hemocyanin and ferritin from lobsters had extremely high affinities for ${ }^{210} \mathrm{Po}$, and Stepnowski \& Skwarzec (2000) found the highest ${ }^{210} \mathrm{Po}$ activities (>540 Bq kg ${ }^{-1}$ dry wt) and highest ${ }^{210} \mathrm{Po}:{ }^{210} \mathrm{~Pb}$ activity ratios in the hepatopancreas of Baltic crustaceans. In particular, they found that $60 \%$ of the total ${ }^{210} \mathrm{Po}$ in these crustaceans was bound to the cytosolic fraction of the hepatopancreas. These findings are consistent with and provide a mechanistic explanation for our assimilation results.

Further, the contrast that we observed between ${ }^{210} \mathrm{Po}$ and ${ }^{210} \mathrm{~Pb}$ in interactions with marine plankton can help explain oceanographic observations on the divergent bioaccumulation patterns and residence times of these radionuclides. The mean ${ }^{210} \mathrm{Po}:{ }^{210} \mathrm{~Pb}$ activity ratios in Artemia sp. (5) and euphausiids (62) are within the range of values measured in various other studies, and can possibly be used as diagnostic tools to evaluate the trophic structure of other pelagic animals. For example, net zooplankton off the Cape of Good Hope had activity ratios between 9 and 25 (Shannon et al. 1970), suggesting that the animals were an assemblage of herbivores and carnivores, or that the animals caught were omnivores feeding opportunistically on a mixed diet. Cherry \& Heyraud (1981) reported an average ${ }^{210} \mathrm{Po}:{ }^{210} \mathrm{~Pb}$ activity ratio of 77 for more than 30 different species of pelagic shrimps from various water bodies, and Carvalho \& Fowler (1993) found that the Mediterranean shrimp Lysmata seticaudata had an activity ratio of 47 . For other invertebrates, ${ }^{210} \mathrm{Po}:{ }^{210} \mathrm{~Pb}$ activity ratios ranging from 3 to over 100 have been reported (Somasundaran \& Hameed 2000, Stepnowski \& Skwarzec 2000, Ugur et al. 2002). Our study provides an ecological framework within which ${ }^{210} \mathrm{Po}:{ }^{210} \mathrm{~Pb}$ ratios can be interpreted.

In considering the implications of our assimilation results, in which ${ }^{210} \mathrm{Po}$ displayed significantly greater assimilation and longer retention than ${ }^{210} \mathrm{~Pb}$ in zooplankton, it is expected that ${ }^{210} \mathrm{Po}$ would be recycled biologically in surface waters to a much greater extent 
than ${ }^{210} \mathrm{~Pb}$, consistent with oceanographic observations (Nozaki et al. 1997). Further, it would be expected that the residence time of ${ }^{210} \mathrm{~Pb}$ in surface waters would be relatively short (Cochran et al. 1983, Masqué et al. 2002), especially in waters in which the zooplankton biomass is high (Fisher \& Fowler 1987), as sinking fecal pellets enriched in this isotope retain it for periods long enough to transport it to deep waters (Fisher et al. 1987).

The bioaccumulation of ${ }^{210} \mathrm{Po}$ in Meganyctiphanes norvegica is of interest in part because krill can be an integral part of the marine food chain in the Atlantic, Antarctic and Mediterranean. For example, Tarling et al. (2001) reported that euphausiids dominated the fall plankton community in the Ligurian Sea, where our euphausiids were collected. In addition, as found in our study, 2 distinct cohorts of $M$. norvegica are normally present in the Ligurian Sea: a born-in-the-year group (smaller individuals) and an older (1 yr +) cohort (larger individuals) (Labat \& Cuzin-Roudy 1996). Because of the omnivorous nature of euphausiids, this species directly connects the phytoplankton, which are the first point of entry for ${ }^{210}$ Po into marine food webs, with larger invertebrates and vertebrates, and forms a link between copepods and other small grazers with higher trophic levels. Thus, while the bioaccumulation of ${ }^{210} \mathrm{Po}$ by euphausiids is an important step in its cycling in marine systems, it also may influence the extent to which this radionuclide builds up in marine organisms (including krill themselves) that are harvested for human consumption or for animal feed.

Acknowledgements. We thank J. C. Miquel, A. M. Rodriguez y Baena, and B. Gasser for their help with zooplankton collection. This work was funded by NSF grants OPP 9986069 and OCE 0136370001, and a DOD NDSEG fellowship to G.M.S. The IAEA Marine Environmental Laboratory operates under a bipartite agreement between the IAEA and the Government of the Principality of Monaco. This is MEDFLUX contribution no. 2 and MSRC contribution no. 1287.

\section{LITERATURE CITED}

Aarkrog A, Baxter MS, Bettencourt AO, Bojanowski R and 16 others (1997) A comparison of doses from ${ }^{137} \mathrm{Cs}$ and ${ }^{210} \mathrm{Po}$ in marine food: a major international study. J Environ Radioact 34:69-90

Antezana TJ, Fowler SW (1972) Gamma emitters in euphausiids from the Southeast Pacific Ocean. Health Phys 22: 201-205

Bozzano A, Recasens L, Sartor P (1997) Diet of the European hake Merluccius merluccius (Pisces: Merluciidae) in the Western Medietarrean (Gulf of Lions). Sci Mar 61:1-8

Buchholz F, Saborowski R (2000) Metabolic and enzymatic adaptions in northern krill, Meganyctiphanes norvegica, and Antarctic krill, Euphausia superba. Can J Fish Aquat Sci 57:115-129

Bustamante P, Germain P, Leclerc G, Miramand P (2002) Concentration and distribution of Po-210 in the tissues of the scallop Chlamys varia and the mussel Mytilus edulis from the coast of Charente-Maritime (France). Mar Pollut Bull 44:997-1002

Cabral HN, Murta AG (2002) The diet of blue whiting, hake, horse mackerel and mackerel off Portugal. J Appl Ichthyol 18:14-23

Carvalho FP, Fowler SW (1993) An experimental study on the bioaccumulation and turnover of Po-210 and Pb-210 in marine shrimp. Mar Ecol Prog Ser 102:125-133

Carvalho FP, Fowler SW (1994) A double-tracer technique to determine the relative importance of water and food as sources of Po-210 to marine prawns and fish. Mar Ecol Prog Ser 103:251-264

Cherry RD, Heyraud M (1981) Polonium-210 content of marine shrimp: variation with biological and environmental factors. Mar Biol 65:165-175

Cherry RD, Heyraud M (1982) Evidence of high natural radiation doses in certain mid-water oceanic organisms. Science 218:54-56

Cherry RD, Fowler SW, Beasley TM, Heyraud M (1975) Polonium-210: its vertical oceanic transport by zooplankton metabolic activity. Mar Chem 3:105-110

Cochran JK, Bacon M, Krishnaswami S, Turekian K (1983) ${ }^{210} \mathrm{Po}$ and ${ }^{210} \mathrm{~Pb}$ distributions in the central and eastern Indian Ocean. Earth Planet Sci Lett 65:433-452

Cristo M, Cartes JE (1998) A comparative study of the fedding ecology of Nephrops norvegicus (L.) (Decapoda: Nephropidae) in the bathyl Mediterranean and the adjacent Atlantic. Sci Mar 62(Suppl 1):81-90

Durand JP, Goudard F, Barbot C, Pieri J, Fowler SW, Cotret O (2002) Ferritin and hemocyanin: Po-210 molecular traps in marine fish, oyster and lobster. Mar Ecol Prog Ser 233: 199-205

Fisher NS, Fowler SW (1987) The role of biogenic debris in the vertical transport of transuranic wastes in the sea. In: O'Connor TP, Burt WV, Duedall IW (eds) Oceanic processes in marine pollution, Vol 2, Physicochemical processes and wastes in the ocean. Krieger, Malabar, p 197-207

Fisher NS, Reinfelder JR (1995) The trophic transfer of metals in marine systems. In: Tessier A, Turner DR (eds) Metal speciation and bioavailability in aquatic systems. John Wiley \& Sons, Chichester, p 363-406

Fisher NS, Bjerregaard P, Fowler SW (1983a) Interactions of marine plankton with transuranic elements. III. Biokinetics of americium in euphausiids. Mar Biol 75:261-268

Fisher NS, Burns KA, Cherry RD, Heyraud M (1983b) Accumulation and cellular distribution of ${ }^{241} \mathrm{Am},{ }^{210} \mathrm{Po}$, and ${ }^{210} \mathrm{~Pb}$ in 2 marine algae. Mar Ecol Prog Ser 11:233-237

Fisher NS, Teyssié JL, Krishnaswami S, Baskaran M (1987) Accumulation of $\mathrm{Th}, \mathrm{Pb}, \mathrm{U}$, and Ra in marine phytoplankton and its geochemical significance. Limnol Oceanogr 32:131-142

Fisher NS, Breslin VT, Levandowsky M (1995) Accumulation of silver and lead in estuarine microzooplankton. Mar Ecol Prog Ser 116:207-215

Flynn WW (1968) Determination of low levels of polonium-210 in environmental materials. Anal Chim Acta 43:221-227

Fowler SW (1977) Trace elements in zooplankton particulate products. Nature 269:51-53

Fowler SW, Knauer GA (1986) Role of large particles in the transport of elements and organic compounds through the oceanic water column. Prog Oceanogr 16:147-194

Friedrich J, Rutgers van der Loeff M (2002) A 2 tracer $\left({ }^{210} \mathrm{Po}-{ }^{234} \mathrm{Th}\right)$ to distinguish organic carbon and biogenic silica export flux in the Antarctic Circumpolar Current. Deep-Sea Res 49:101-120 
Guillard RRL, Ryther JH (1962) Studies of marine planktonic diatoms I. Cyclotella nana Hustedt, and Detonula confervacea (Cleve) Gran. Can J Microbiol 8:229-239

Heldal HE, Foyn L, Varskog P (2003) Bioaccumulation of Cs137 in pelagic food webs in the Norwegian and Barents Seas. J Environ Radioact 65:177-185

Heyraud M, Cherry RD (1979) Polonium-210 and lead-210 in marine food chains. Mar Biol 52:227-236

Heyraud M, Fowler SW, Beasley TM, Cherry RD (1976) Polonium-210 in euphausiids: a detailed study. Mar Biol 34: $127-136$

Heyraud M, Cherry RD, Dowdle E (1987) The subcellular localization of natural ${ }^{210} \mathrm{Po}$ in the hepatopancreas of the rock lobster (Jasus lalandii). J Environ Radioact 5: 249-260

Heyraud M, Domanski P, Cherry RD, Fasham M (1988) Natural tracers in dietary studies: data from ${ }^{210} \mathrm{Po}$ and ${ }^{210} \mathrm{~Pb}$ in decapod shrimp and other pelagic organisms in the Northeast Atlantic Ocean. Mar Biol 97:507-519

Higgo JJW, Cherry RD, Heyraud M, Fowler SW (1977) Rapid removal of plutonium from the oceanic surface layer by zooplankton faecal pellets. Nature 266:623-624

IAEA (International Atomic Energy Agency) (2004) Sediment distribution coefficients and concentration factors for biota in the marine environment. IAEA Tech Rep Ser 422, IAEA, Vienna

Kils U, Klages N (1979) Der Krill. Naturwiss Rundsch 32: 397-402

Labat JP, Cuzin-Roudy J (1996) Population dynamics of the krill Meganyctiphanes norvegica (M Sars, 1957) Crustacea: Euphausiacea) in the Ligurian Sea (NW Mediterranean Sea). Size structure, growth and mortality modeling. J Plankton Res 18:2295-2312

Locarini SJP, Presley BJ (1995) Trace element concentrations in Antarctic krill, Euphausia superba. Polar Biol 15:283-288

Marzano FN, Fiori F, Jia GG, Chiantore M (2000) Anthropogenic radionuclides bioaccumulation in Antarctic marine fauna and its ecological relevance. Polar Biol 11:753-758

Masqué P, Sanchez-Cabeza JA, Bruach JM, Palacios E, Canals M (2002) Balance and residence times of $\mathrm{Pb}-210$ and Po-210 in surface waters of the northwestern Mediterranean Sea. Cont Shelf Res 22:2127-2146

Mayzaud P, Virtue P, Albessard E (1999) Seasonal variations in the lipid and fatty acid composition of the euphausiid Meganyctiphanes norvegica from the Ligurian Sea. Mar Ecol Prog Ser 186:199-210

Nozaki Y, Zhang J, Takeda A $(1997){ }^{210} \mathrm{~Pb}$ and ${ }^{210} \mathrm{Po}$ in the equatorial Pacific and the Bering Sea: the effects of biological productivity and boundary scavenging. Deep-Sea Res 44:2203-2220

Nygard T, Lie E, Rov, N, Steinnes E (2001) Metal dynamics in an Antarctic food chain. Mar Pollut Bull 42:598-602

Reinfelder JR, Fisher NS (1991) The assimilation of elements ingested by marine copepods. Science 251:794-796

Reinfelder JR, Fisher NS, Luoma SN, Nichols JW, Wang WX (1998) Trace element trophic transfer in aquatic organ-

Editorial responsibility: Otto Kinne (Editor-in-Chief), Oldendorf/Luhe, Germany isms: a critique of the kinetic model approach. Sci Total Environ 219:117-135

Rupert E, Barnes R (1994) Invertebrate zoology, 6th edn. Saunders College Publishing, New York

Shannon LV, Cherry RD (1967) Polonium-210 in marine plankton. Nature 216:352-353

Shannon LV, Cherry RD, Orren MJ (1970) Polonium-210 and lead-210 in the marine environment. Geochim Cosmochim Acta 34:701-711

Somasundaran SSN, Hameed PS (2000) Polonium-210 in bivalve mollusks of the Gulf of Mannar, southeast coast of India. Indian J Mar Sci 29:263-267

Stepnowski P, Skwarzec B (2000) Tissue and subcellular distributions of Po-210 in the crustacean Saduria entomen inhabiting the southern Baltic Sea. J Environ Radioact 49: 195-199

Stewart GM, Fisher NS (2003a) Experimental studies on the accumulation of polonium-210 by marine phytoplankton. Limnol Oceanogr 48:1193-1201

Stewart GM, Fisher NS (2003b) Bioaccumulation of polonium210 in marine copepods. Limnol Oceanogr 48:2011-2019

Stoeppler M, Brandt K (1979) Comparative studies on trace metal levels in marine biota. 2. Trace metals in krill, krill products, and fish from the Antarctic Scotia Sea. Z Lebensm-Unters Forsch 169:95-98

Tarling GA, Matthews JBL, David P, Guerin O, Buchholz F (2001) The swarm dynamics of northern krill (Meganyctiphanes norvegica) and pteropods (Cavolinia inflexa) during vertical migrations in the Ligurian Sea observed by an acoustic Doppler current profiler. Deep-Sea Res I 48: $1671-1686$

Thomas P, Tracy B, Ping T, Wickstrom M, Sidhu N, Hiebert L (2003) Relative biological effectiveness (RBE) of Po-210 alpha particles versus X-rays on lethality in bovine endothelial cells. Int J Radiat Biol 79:107-118

Twining BS, Fisher NS (2004) Trophic transfer of trace metals from protozoa to mesozooplankton. Limnol Oceanogr 49: 28-39

Ugur A, Yener G, Bassari A (2002) Trace metals and Po-210 (Pb-210) concentrations in mussels (Mytilus galloprovincialis) consumed at western Anatolia. Appl Radiat Isot 57:565-571

Virtue P, Mayzaud P, Albessard E, Nichols P (2000) Use of fatty acids as dietary indicators in northern krill, Meganyctiphanes norvegica, from northeastern Atlantic, Kattegat, and Mediterranean waters. Can J Fish Aquat Sci 57: $104-114$

Wallace WG, Lopez GR (1996) Relationship between subcellular cadmium distribution in prey and cadmium trophic transfer to a predator. Estuaries 19:923-930

Wang WX, Fisher NS (1999) Delineating metal accumulation pathways for marine invertebrates. Sci Total Environ 237/238:459-472

Wildgust MA, McDonald P, White KN (2000) Assimilation of ${ }^{210} \mathrm{Po}$ by the mussel Mytilus edulis from the alga Isochrysis galbana. Mar Biol 136:49-53

Submitted: August 2, 2004; Accepted: November 16, 2004 Proofs received from author(s): March 18, 2005 